\title{
Potential Water Balance using Rainwater: An Analysis of Delhi, Megacity in India
}

\author{
Priya Sharma ${ }^{1, *}$, Neha Midha ${ }^{2}$
}

${ }^{1}$ Land Resources Division, The Energy and Resources Institute (TERI), 6C Darbari Seth Block, Indian Habitat Center, New Delhi - 110003, India. ${ }^{2}$ UNESCO New Delhi Cluster Office for Bangladesh, Bhutan, India, Nepal, Maldives and Sri Lanka, San Martin Marg, Chanakyapuri, New Delhi - 110021, India.

\section{ART I C LEDETAILS}

\section{Article history:}

Received 27 January 2021

Accepted 13 February 2021

Available online 26 February 2021

\section{Keywords:}

Rainwater Harvesting

Mass Curve Method

Water Scarcity

\begin{abstract}
A B S T R A C T
Delhi is one of the most water stressed cities in the world. This study aimed to explore the potential of Rainwater Harvesting (RWH) as an alternative source of the water supply for Delhi. Mass curve method has been used to understand the feasibility of RWH, indicating that an average roof of $60 \mathrm{~m}^{2}$ in Delhi will collect 3,64,800 L of water in a year for an average family size of five people. The present study assumed that financial constraints, erratic rainfall, unclear legal guidelines, poor public perception, and a lack of commitment from the politicians are possible challenges.
\end{abstract}

\section{Introduction}

Water is the prime determinant of sustainability in urban areas [1]. Right from ancient times, civilizations have flourished near water bodies. However, available water supply is now diminishing owing to the population explosion, rapid urbanization, climate change, and pollution, causing a globally acknowledged situation of water scarcity [2]. In the global cities, the municipalities are struggling to provide better water management infrastructure to their growing population.

Most urban growth over the next 5 years will be concentrated in developing nations in Asia and Africa [3]. Due to the increased impact of climate change and population expansion many countries in Asia and the Pacific are emerging as the hot spot for water insecurity. In the year 2016, out of 48 countries, 29 countries in this area fit as water-insecure due to low availability of water and unsustainable groundwater extraction [4]. Because of obsolete water supply systems and insufficient infrastructure to harvest and store rainwater, several large as well as medium-sized cities in these countries face the jeopardy of water shortage [5].

India, the world's largest user of groundwater represents 25 percent of global groundwater withdrawals [6]. Groundwater contributes to almost more than $60 \%$ of irrigated agriculture and almost $85 \%$ of drinking water supplies across the globe are dependent on groundwater [6]. Correspondingly, agriculture withdraws $89 \%$ of available "surface water" too. By 2020, India is foreseen as a water-stressed country and 21 major cities, including the capital, Delhi, are expected to reach zero groundwater levels, affecting access for 100 million people [7].

\subsection{Water Scenario in Delhi: Water Supply and Demand Variation}

Delhi is one of the 10 largest cities in the world. With the fast-growing rate of urbanization, it is the second most water-stressed city in the world. Through an existing water supply network encompassing of 14,355 km long pipelines and more than 107 underground reservoirs spread across New Delhi, at present water is being supplied to about 18 million populations residing in New Delhi [8]. The growing population, rapid urbanization, and industrialization in Delhi are putting remarkable pressure on water resources availability. The Central Ground Water Board of India assessed the total groundwater potential in Delhi to be 292 million cubic meters (MCM) in 2003 as compared to 428.07 MCM in 1983, showing an overdraft and reduction of around 130 MCM in 20 years [9]. Further, water authorities reported declining groundwater levels in the year 2018 from $0.5 \mathrm{~m}$ to $2 \mathrm{~m}$ per year in the last two decades, rating $90 \%$ of the city as semi-critical or critical zone [10].

The average annual rainfall in Delhi is $611 \mathrm{~mm}$ [10]. However, recharge of groundwater in New Delhi gets restricted due to decreased availability of permeable surfaces which are a subsequent effect of urbanization, the runoff gets diverted into the sewers or stormwater drains. Furthermore, the unplanned and unsustainable withdrawal from the subsoil aquifers due to the irregular supply of water by authorities, have been primarily responsible for the decline in groundwater levels.

Water treatment and supply capacity of Delhi Water Authorities, which was 66 MGD (Million Gallons per Day) in 1956, was raised to 240 MGD in 1979, 437 MGD in 1990, 650 MGD in 2002, and 906 MGD in 2014 [8]. The authorities have been raising concern that the present infrastructure and with existing resources, the projected demand in 2021 of 1380 MGD for the projected increased population of 23 million cannot be met, and there will be a shortfall of about 440 MGD [8].

Thus, the severe water shortages likely to be faced by Delhi require a comprehensive approach to manage both water supply and water demand. While the government has placed a priority on meeting domestic water needs, the importance of the commercial, industrial, and agricultural sectors necessitates a considered approach to improve water security.

Water Policy for Delhi mentions a number of goals and actions to address the water supply-demand imbalance and has recognized the importance of "water harvesting" [1]. A described by Yazar et al. [11], "Water harvesting" is the process of concentrating precipitation through runoff and storage for productive use. The annual rainwater harvesting potential has been assessed at 2500 million liters per day for Delhi [8]. Even if a quarter of this could be reaped it would imply the availability of 625 million liters per day, which would be closely equal to the presently estimated shortage. This will be in addition to the potential for roof water harvesting measured at around 27 million liters per day [8].

\subsection{Rainwater Harvesting for Megacities}

Rainwater Harvesting (RWH) has drawn the interest of researchers and policymakers as a sustainable source to meet the increasing water demand and one of the most suitable sustainable solutions to be included in the urban water management system [12]. Multiple paybacks of the RWH systems include mitigation of the water crisis issues, reduce the load on traditional water sources, lighten non-point source pollutant loads, control water logging problems, prevent flash-floods floods, mitigate climate change impacts, contribute to stormwater management, and so forth [12]. The RWH system has been utilized all around the world locally and commercially for securing water demand as in large public institution [13]; domestic; irrigation, industries, etc., [13-15]. Hence, evaluating the 
feasibility of RWH as an alternative source for securing water demand for megacities is potential scope for research.

The economic and environmental benefits associated with rainwater harvesting systems as possible sustainable solutions towards the water scarcity issues in the urban areas of Colombo, Sri Lanka [16]. The potential for rainwater harvesting in the major ecological zones of Nigeria and furthermore, classified residential buildings into different classes with different amounts of water consumption in order to focus on flood mitigation and domestic water supply [17]. It was inferred from the results that the rainwater harvesting potential was a power function of rainfall coefficient of variation as the reliability of the system was over $80 \%$ for the rainforest and guinea savanna zone. The potential for potable water savings by using rainwater for the residential sector of 62 cities in the state of Santa Catarina, Brazil. They found that it ranges from 34\% to $92 \%$ depending on the potable water demand in the cities, with an average potential for potable water savings of $69 \%$ [18].

A study conducted by Mehrabadi and Motevalli in 2012, modeled different tank volumes to collect rooftop runoff from residential rooftops to control urban floods in Tehran, Iran, and concluded that with increasing tank size and subsequently the volume of collected water, the frequency of the urban flood decreased [19]. A study conducted by Dwivedi et al in 2013 estimated the rooftop harvesting potential of the buildings which also described the planning and scheming of the Rain water harvesting systems as well as their delivery system, and the groundwater recharge system for a town in India called as Dhule. The study found that the unit cost of water appeared to be high in comparison to the market price, however, the environmental benefits of the groundwater recharging with good quality water validates such projects [20]. Clark et al. in 2015 simulated runoff, recharge, and recovery for different rainfall, catchment, and aquifer conditions, and working scenarios for Salisbury, South Australia estimating that the annual demand associating to $12.8 \%$ of catchment rainfall could be met with $99.5 \%$ volumetric reliability [21]. Adguna et al. through their study showed that there is a high potential contribution of rooftop RWH from large public institutions which can supplement the potable water demand. He also described the relation among the rainwater harvest to city level consumption and consumption at the individual institution for the water-stressed city of Addis Ababa in Ethiopia [2].

With this background of clear evidence of dwindling water resources in the Megacity of Delhi and escalating water demand, though this paper we aim to evaluate the potential for water balance in the city of Delhi through the technique of rainwater harvesting.

\section{Experimental Methods}

The present study evaluates the reliability of rainwater as an alternative water supply for the Megacity of Delhi. The methods that have been widely investigated to understand the performance and design of RWH systems worldwide, include water balance simulation analyses, mass curve analyses [22, 23); probabilistic method; and economic optimization [2225]. The unequal distribution and seasonal concentration of rainfall is so great in Delhi that even a small demand can't be met during dry periods and storage facilities must be built to save water during wetter periods. The reservoir should be large enough to provide dependable supply but should not be unnecessarily large covering unnecessarily more space, more investment, and more pressure on underlying slope forming materials. So the rational calculation for reservoir size has to be made.

In the present study, proper reservoir size has been estimated using the mass curve method, which calculates the difference between the total water flowing in and the water demanded to estimate the quantity that the reservoir must hold if the demand is to be met. Further, the feasibility has been assessed through understanding construction-materials of roofs and calculating the monthly yield of water-discharge from the rooftop of average size in relation to average monthly rainfall. The amount of water yield from a rooftop and that of demand are then plotted to construct mass curve for calculating the reservoir size for a family of modal constituents of 5 members to meet average demand in the dry period.

A mass curve of inflow is plotted between cumulative inflow values against time. Similarly, the mass curve of demand is plotted between accumulated demand and time. Ultimately, the capacity of a storage reservoir required for a specified yield or demand is determined by using the mass curve of inflow and mass curve of demand or demand curve. The demand lines which are drawn tangent to the tall points of the mass curve characterize the rate of withdrawal from the reservoir [26].

\subsection{Rainfall Variability}

Two decades of data related to the daily rainfall was obtained from the Indian Meteorological Department and was analyzed to estimate the https://doi.org/10.30799/jespr.211.21070102 average monthly rainfall for Delhi city (Fig. 1). The figure shows that heavy rainfall is concentrated in the months from May to September. The precipitation received from October to April is in-adequate to meet the demand during this period. Thus, the storage of rainwater during the rainy season is a necessity for the rest of the year.

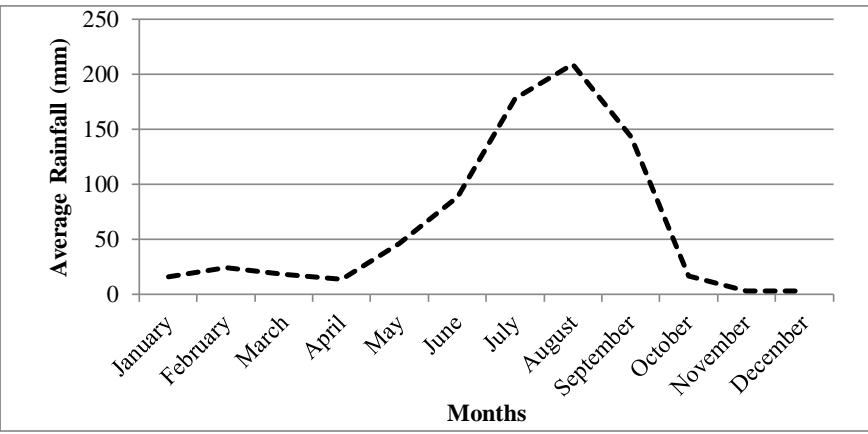

Fig. 1 Average monthly rainfall distribution for Delhi calculated from the year 1997 to 2017

\subsection{Household Size}

Household size is one of the crucial parameters in designing an RWH system specifically by using the mass curve analysis method [27]. The calculation for finding RWH potential is based on the total water demand, storage volume, and catchment area. The average size of a household is 4.55 persons according to the Directorate of Economics \& Statistics, Government of NCT of Delhi [28]. The average household size is taken as 5 for the calculation of design storage capacity in the present study.

\subsection{Roofing Material}

The roofing materials used in Delhi include brick, wood, iron sheets, cement concrete, and roofing tiles. There are about $99.10 \%$ of proper 'pucca' houses (solid and permanent houses), $0.68 \%$ of 'semi - pucca' (either roof or wall is not made up of solid material like burnt bricks, stone, cement, concrete or timber) and rest only $0.22 \%$ of 'kutcha' houses (houses made from mud, thatch, or other low-quality materials) [29]. Thus the roofing materials of these houses specifically 'pucca' are suitable for rainwater catchment to be used for non-potable purposes.

\subsection{Roofing Size}

Of the dwellings located in the urban area of Delhi, $51.1 \%$ on average are individual houses and $46.5 \%$ are flats [29]. Therefore, as there are no official data on Rooftop Area (RA), an area of $83.6 \mathrm{~m}^{2}$ has been assumed for houses and $6.00 \mathrm{~m}^{2}$ per person for flats in the urban area (this gives approximately $30.00 \mathrm{~m}^{2}$ of Rooftop area per flat) [30]. In the next step, a weighted average rooftop area per dwelling was then determined by using Eq. (1) [31].

$$
\mathrm{RA}=(\mathrm{H} \times 83.6+\mathrm{F} \times 30.00) / 100
$$

In the above formula, 'RA' stands for the weighted average of Rooftop area per dwelling in the city $\left(\mathrm{m}^{2}\right)$, $\mathrm{H}$ represents the percentage of houses in the city (non-dimensional) whereas F signifies the percentage of flats in the city (non-dimensional). By applying Eq. (1), the average RA obtained for the city was $56.68 \mathrm{~m}^{2}$ which is about $60 \mathrm{~m}^{2}$.

\subsection{Catchment Surface}

The runoff coefficient specific to various types of surfaces of rooftops is shown in Table 1 [32] derived from the Eq.(2). A runoff coefficient 0.8 was used for this study since the houses in New Delhi are mostly 'Pucca' houses and the rooftops are made up of concrete [33].

Runoff $=\mathrm{CiA}$

where $\mathrm{C}$ is the coefficient of runoff, $\mathrm{i}$ is the rainfall intensity, and $\mathrm{A}$ is the roof area.

Table 1 Runoff coefficients for different catchment surfaces

\begin{tabular}{ll}
\hline Surface & Co-efficient \\
\hline Tiles & $0.8-0.9$ \\
Corrugated metal sheets & $0.7-0.9$ \\
Concrete & $0.6-0.8$ \\
Brick pavement & $0.5-0.6$ \\
The soil on slopes less than 10 percent & $0.0-0.3$ \\
Rocky natural catchments & $0.2-0.5$ \\
Green area & $0.05-0.10$ \\
\hline
\end{tabular}




\section{Results and Discussion}

\subsection{Mass Curve to Derive the Storage Tank Capacity}

To evaluate the potential of rainwater as an alternative water supply in Delhi, the mass curve approach has been used in this study. The mass curve has been prepared by calculating cumulated rainwater harvested using the average monthly rainfall, assumed rooftop area of $60 \mathrm{~m}^{2}$, and a runoff coefficient of 0.8 to estimate the monthly runoff harvested (Table 2). The mass curve has been prepared by plotting cumulative runoff harvested and considering the constant withdrawal for a whole year. The maximum gap between these two determines the rational reservoir size to meet the demand for water for the concerned year (Fig. 2).

Table 2 The cumulative harvested water calculated for the city of Delhi

\begin{tabular}{llllll}
\hline Month & $\begin{array}{l}\text { Average } \\
\text { Rainfall } \\
{[\mathrm{i}](\mathrm{mm})}\end{array}$ & $\begin{array}{l}\text { Roof Area } \\
{[\mathrm{RA}]} \\
\left(\mathrm{m}^{2}\right)\end{array}$ & $\begin{array}{l}\text { Runoff } \\
\text { Coefficient } \\
{[\mathrm{C}]}\end{array}$ & $\begin{array}{l}\text { Monthly } \\
\text { Runoff } \\
\text { Harvested } \\
{\left[\mathrm{i} \text { x RA x C] }\left(\mathrm{m}^{3}\right)\right.}\end{array}$ & $\begin{array}{l}\text { Cumulative } \\
\text { runoff } \\
\text { Harvested }\left(\mathrm{m}^{3}\right)\end{array}$ \\
\hline January & 16 & 60 & 0.8 & 7.68 & 7.68 \\
February & 24 & 60 & 0.8 & 11.52 & 19.2 \\
March & 18 & 60 & 0.8 & 8.64 & 27.84 \\
April & 14 & 60 & 0.8 & 6.72 & 34.56 \\
May & 46 & 60 & 0.8 & 22.08 & 56.64 \\
June & 89 & 60 & 0.8 & 42.72 & 99.36 \\
July & 178 & 60 & 0.8 & 85.44 & 184.8 \\
August & 209 & 60 & 0.8 & 100.32 & 285.12 \\
September & 143 & 60 & 0.8 & 68.64 & 353.76 \\
October & 17 & 60 & 0.8 & 8.16 & 361.92 \\
November & 3 & 60 & 0.8 & 1.44 & 363.36 \\
December & 3 & 60 & 0.8 & 1.44 & 364.8 \\
\hline
\end{tabular}

The analysis of the result of mass curve derivation revealed that the rooftop with an area of $60 \mathrm{~m}^{2}$ can collect 3,64,800 L runoff every year. Thus, assuming a constant withdrawal throughout the year, the volume of water collected will be $999.45 \mathrm{~L} /$ day. For a family of five people, this means $200 \mathrm{~L} /$ person/day, which is quite a substantial amount of water in urban areas like Delhi, provided there is sufficient storage infrastructure. Furthermore, Fig. 2 presents that the maximum storage is required in September with an additional storage capacity of $94 \mathrm{~m}_{3}(94,000 \mathrm{~L})$.

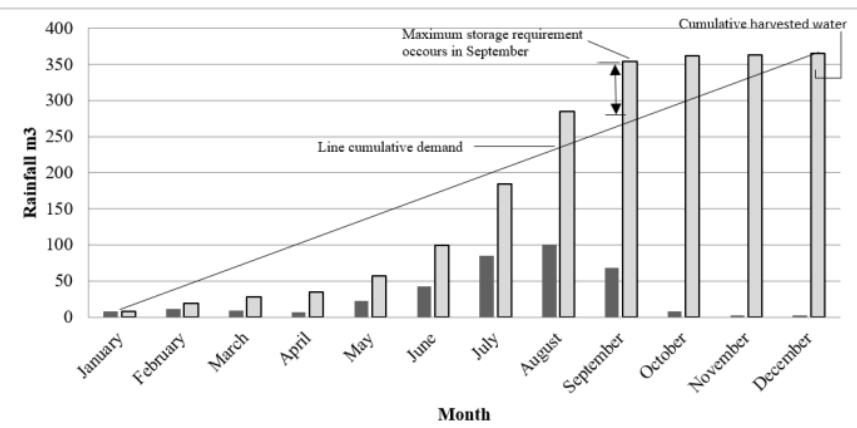

- Monthly Runoff Harvested RCumulative Runoff Harvested

Fig. 2 Mass curve of cumulative demand vs. cumulative rainwater harvested for Delhi

Comparing the present study with another similar study, it was observed that a 4,000 L concrete tank installed with a roof area of $40 \mathrm{~m}^{2}$ was adequate to take care of the water demands of a household consisting of four members [34, 35]. Similarly, a study conducted by Woltersdorf et al. in 2015 recommended that a rooftop of $100 \mathrm{~m}^{2}$ should have a tank size of $30 \mathrm{~m}^{3}$, while according to Ndiritu et al. a storage tank size of $40 \mathrm{~m}^{3}$ optimum for a roof size area range between $75 \mathrm{~m}^{2}$ and $150 \mathrm{~m}^{2}[36,37]$. According to Imteaz et al., a tank size of $7,000 \mathrm{~L}$ is required to achieve $100 \%$ reliability for toilet flushing and laundry [38].

The present study recommends that the rooftop RWH should be considered as one of the alternative sources of the water supply system for the water scare Delhi megacity and for the megacities of the future. The application of RWH is technically feasible based on the prevailing rainfall pattern. According to the data available, over $90 \%$ of households have a rooftop constructed from technically appropriate materials like concrete. Results of the research performed in New Delhi indicate that an average roof of $60 \mathrm{~m}^{2}$ will collect 3,64,800 L/yr (999.45 L/person/day) for an average family size of five people. This amount of water can be used to easily used to fulfill the demand for drinking and cooking purposes. Thus, domestic rainwater harvesting is highly encouraged as a supplementary water source and also a means for groundwater recharge especially in urban and peri-urban areas to reduce the vulnerability of the acute shortage of water resources. Therefore, the objective of this study was to estimate the potential contribution of rooftop RWH from Residential areas to supplement the potable water demand and relate the rainwater harvest to city level consumption.

Rainwater harvesting being widely practiced across the globe but there are still some major concerns and barriers that exists in its wide scale implementation. The concerns of RWH especially in the developing world could be financed, followed by the volume of water depending on erratic rainfall, calling for large water storages, the inability to link with the present water system, no clear legal guidelines, poor public perception, and a lack of commitment from the politicians. Although RWH in Delhi is being encouraged by Delhi Master Plan 2021 and Delhi Water Policy 2017 guidelines but practiced only at an insignificant level with few, small-scale traditional practices at household levels and mandatory for new residential and commercial building usage is for some non-potable applications.

\section{Conclusion}

Using Delhi as a case to represent rapidly developing cities in South Asia struggling with water scarcity, the idea of this study was to estimate the potential of RWH for water balance in the city of Delhi through the technique of rainwater harvesting. Results of the present research indicated that an average roof of $60 \mathrm{~m}^{2}$ in Delhi will collect 3, 64, 800 liters of water in a year ( $999.45 \mathrm{~L} /$ person/day) for an average family size of five people. This amount of water is sufficient to fulfill the demand for all domestic purposes and also a means for groundwater recharge especially in urban and peri-urban areas to reduce the vulnerability of acute shortage of water resources in dry seasons. Thus, to narrow the water supply gap, considering RWH as an alternative water supply source is recommended through this study. It was also analyzed during the study that various aspects such as the high investment costs for rainwater harvesting facilities, short-term tenancy arrangements, and the perception among the users that rainwater is not clean have emerged as limiting factors for the domestic use of rainwater. However, the present study assumed that financial constraints, erratic rainfall calling for large water storages, the inability to link with the present water system, with no clear legal guidelines, poor public perception, and a lack of commitment from the politicians are considered as possible challenges.

\section{Acknowledgment}

The authors would be like to acknowledge Mr. Guy Broucke, Programme Specialist for Natural Sciences, UNESCO New Delhi Cluster Office for his advice and support.

\section{References}

[1] Delhi Jal Board and Indian National Trust for Art and Cultural Heritage, Water policy for Delhi, Govt. of the national capital territory of Delhi, New Delhi, 2018. http://naturalheritage.intach.org/wp-content/uploads/2018/04/WaterPolicy-Delhi.pdf (Accessed on: 22 nd June 2020)

[2] D. Adugna, M. Jensen, B. Lemma, G. Gebrie, Assessing the potential for rooftop rainwater harvesting from large public institutions, Int. J. Environ. Res. Public Health 15(2) (2018) 336-338.

[3] United Nations, World urbanization prospects: The 2014 Revision, Population Division (ST/ESA/SER.A/366), Department of Economic and Social Affairs (2015). https://population.un.org/wup/Publications/Files/WUP2014Report.pdf (Accessed on: 15 th June 2020)

[4] Asian Water Development Outlook 2016, Strengthening Water Security in Asia and Pacific, Asian Development Bank, Mandaluyong City, Philippines, 2016. https://www.adb.org/sites/default/files/publication/189411/awdo2016.pdf (Accessed on: $31^{\text {st }}$ May 2020)

[5] The United Nations World Water Development Report 2019, Leaving No One Behind, UNESCO, 2019. https://en.unesco.org/themes/watersecurity/wwap/wwdr/2019 (Accessed on: $22^{\text {nd }}$ August 2020)

[6] Program Appraisal Document on a proposed loan to Republic of India for an Atal Bhujal Yojana - National Groundwater Improvement, The World Bank 2018. http://documents1.worldbank.org/curated/en/697581528428694246 /pdf/ India-PAD-126071-IN-05162018.pdf (Accessed on: 2nd August 2020)

[7] Composite Water Management Index, A tool for water management, Niti Aayog, Government of India, New Delhi, 2018 https://niti.gov.in/writereaddata/files/document_publication/2018-05-18Water-index-Report_vS6B.pdf (Accessed on: 22nd May 2020)

[8] Economic Survey of Delhi 2018, Delhi Government, New Delhi, 2018 http://delhi.gov.in/DoIT/DoIT_Planning/ESEng.pdf (Accessed on: 5th July 2020)

[9] Master Plan for Delhi 2021, Delhi Development Authority, Government of Delhi, New Delhi, 2010. http://52.172.182.107/BPAMSClient/seConfigFiles/ Downloads/MPD2021.pdf (Accessed on: 11 th July 2020) 
[10] Aquifer mapping and ground water management plan of NCT Delhi, Central Ground Water Board - State Unit Office, New Delhi, 2016. http://cgwb.gov.in/AQM/NAQUIM_REPORT/Delhi/old/Naquim\%20Report\% 20Delhi\%20.pdf (Accessed on: $2^{\text {nd }}$ August 2020)

[11] A. Yazar, A. Ali, Water harvesting in dry environments, in: Md. Farooq, Kadambot H.M. Siddique, Innovations in Dryland Agriculture, Springer International Publishing, Switzerland, 2016, pp.49-98.

[12] S. Rahman, M. Khan, S. Akib, N. Din, S. Biswas, S. Shirazi, Sustainability of rainwater harvesting system in terms of water quality, Sci. World Jour. 2014 (2014) 721357:1-10.

[13] M. Zaizen, T. Urakawa, Y. Matsumoto, H. Takai, The collection of rainwater from dome stadiums in Japan, Urban Water 1(4) (2000) 355-359.

[14] M. Mathur, Modelling rainwater-harvesting system reliability based on historical precipitation data for Portland, Civil and Environmental Engineering Master's Project Reports, Portland State University, Portland, Oregon, 2014.

[15] B. Biazin, G. Sterk, M. Temesgen, A. Abdulkedir, L. Stroosnijder, Rainwater harvesting and management in rainfed agricultural systems in sub-Saharan Africa - A review, Phys. Chem. Earth A/B/C 47-48 (2012) 139-151.

[16] A. Strand, Urban rainwater harvesting and sustainable water management in Sri Lanka, 2013. https://muep.mau.se/bitstream/handle/2043/15930/ StranUrban\%20Rain\%20Water\%20Harvesting\%20and\%20sustainable $\% 20$ water\%20management $\% 20 \mathrm{in} \% 20$ Sri20 Lanka.pdf? sequence $=2 \&$ isAllowed=y (Accessed on: $10^{\text {th }}$ June 2020)

[17] C.C. Nnaji, N.C. Mama, Preliminary assessment of rainwater harvesting potential in Nigeria: Focus on flood mitigation and domestic water supply, Water Resour. Manag. 28(7) (2014) 1907-1920.

[18] E. Ghisi, A. Montibeller, R.W. Schmidt, Potential for potable water savings by using rainwater: An analysis over 62 cities in southern Brazil, Build. Environ. 41(2) (2006) 204-210.

[19] M. Mehrabadi, M. Motevalli, Operation of Rainwater harvesting on the roofs of residential buildings to reduce of urban flood: A case study in Tehran, Iran, World Appl. Sci. J. 17(2) (2012) 264-270.

[20] A. Dwivedi, V. Patil, A. Karankal, Rooftop rain water harvesting for groundwater recharge in an educational complex, Global J. Res. Eng. 13(1) (2013) 21-30.

[21] R. Clark, D. Gonzalez, P. Dillon, S. Charles, D. Cresswell, B. Naumann, Reliability of water supply from stormwater harvesting and managed aquifer recharge with a brackish aquifer in an urbanizing catchment and changing climate, Environ. Model. Soft. 72 (2015) 117-125.

[22] E.L. Villarreal, A.M. Dixon, Analysis of a rainwater collection system for domestic water supply in Ringdansen, Norrköping, Sweden, Build. Environ. 40(9) (2015) 1174-1184.

[23] B. Panigrahi, S. Panda, B. Mal, Rainwater conservation and recycling by optimal size on-farm reservoir, Resour. Conserv. Recycl. 50(4) (2017) 459-474.

[24] Y. Guo, B. Baetz, Sizing of Rainwater storage units for green building applications, J. Hydro. Eng. 12(2) (2007) 197-205.
[25] C. Liaw, Y. Tsai, Optimum storage volume of rooftop rain water harvesting systems for domestic use, J. Am. Water Resour. Assoc. 40(4) (2004) 901-912.

[26] S. Garg, Irrigation engineering and hydraulic structures: Water resources engineering, 2 ${ }^{\text {nd }}$ Edn., Vikram Jain Books, New Delhi, 2016.

[27] Indian Meteorological Department, Rainfall Information, 2019. http://hydro.imd.gov.in/hydrometweb/(S(cuk04c55sxqwjyvsreufu5yo))/lan ding.aspx (Accessed on: 20th June 2019)

[28] S.A. Ferdausi, M.W. Bolkard, Rainwater harvesting for application in rural Bangladesh, In: J.A. Pickford, P. Deverill, (Eds.), Water, sanitation and hygiene: challenges of the millennium, Proceedings of the 26th WEDC Conference; Dhaka, Bangladesh, 2000.

[29] Housing Conditions in Delhi, Directorate of Economics \& Statistics, Govt. of NCT Delhi, New Delhi, 2014. http://dceast.delhigovt.nic.in/wps/wcm/connect/ 616b1980469d49c9bcb6fc7d994b04ce/69t+rond\%0hosing+cond+final+pdf +report.pdf?MOD=AJPERES\&lmod=1346837056\&CACHEI $=66 \mathrm{~b} 198469 \mathrm{~d} 49 \mathrm{cb}$ cb6fc7d994b04ce (Accessed on: 22 nd April 2020)

[30] Level and pattern of household consumer expenditure in Delhi, Directorate of Economics \& Statistics, Govt. of NCT Delhi, New Delhi, 2012. http://web.delhi.gov.in/DoIT/DES/archive/ses/S64_household_consumer_ex p.pdf (Accessed on: $5^{\text {th }}$ July 2020)

[31] Financial Express, Home buyers looking for bigger flats of average 1,300 sq ft size in Delhi, Gurugram, Mumbai, other top cities, New Delhi, 2013. https://www.financialexpress.com/industry/homebuyers-looking-forbigger-flats-of-average-1300-sq-ft-size-in-delhi-gurugram-mumbai-othertopcities/1219079/ (Accessed on: $16^{\text {th }}$ August 2020)

[32] A. Pacey, A. Cullis, Rainwater harvesting: The collection of rainfall and run-off in rural areas, Intermediate Technology Publications, London, 1989.

[33] Delhi Jal Board, Rainwater Harvesting Guidelines, New Delhi, 2016, http://delhijalboard.nic.in/sites/default/files/AllPDF/RWH_Guidline_13072016_0.pdf (Accessed on: 6 th $^{\text {th }}$ April 2020)

[34] B. Biswas, B. Mandal, Construction and evaluation of rainwater harvesting system for domestic use in a remote and rural area of Khulna, Bangladesh. Int. Scholar. Res. Notices 2014 (2014) 751952:1-7.

[35] O. Lade, D. Oloke, Assessment of rainwater harvesting potential in Ibadan, Nigeria, Environ. Eng. Res. 18(2) (2013) 91-94.

[36] L. Woltersdorf, S. Liehr, R. Scheidegger, P. Döll, Small-scale water reuse for urban agriculture in Namibia: Modelling water flows and productivity, Urban Water J.12(5) (2014) 414-429.

[37] J. Ndiritu, A. Ilemobade, P. Kagoda, Guidelines for rainwater harvesting system design and assessment for the city of Johannesburg, South Africa, Proc. IAHS 379 (2018) 409-414.

[38] M. Imteaz, O. Adeboye, S. Rayburg, A. Shanableh, Rainwater harvesting potential for southwest Nigeria using daily water balance model, Resour. Conserv. Recycl. 62 (2012) 51-55. 